\title{
Formation of organizational and economic mechanisms for innovative development of service sector industries: russian and foreign experience
}

\author{
Viliyan Krastev ${ }^{1}$, Svetlana Pyankova ${ }^{2}$, and Olga Ergunova ${ }^{2}$ \\ ${ }^{1}$ University of Economics-Varna, Knyaz Boris I Blvd., 77, Varna, Bulgaria \\ ${ }^{2}$ Ural State University of Economics, 620144, 8 Marta Str., 62, Ekaterinburg, Russia
}

\begin{abstract}
The article determines the concepts of "service" and "innovation". The article touches upon organizational and economic mechanisms for the innovative development of service sector industries offered by Russian and foreign scientists, in particular in the following spheres: transport, telecommunications, wholesale and retail trade, credit and finance, insurance, consumer services, cultural and recreational services, social services - education, healthcare, and other social services. Methodological recommendations proposed by Russian scientists for the study and implementation of innovations at enterprises in the service sector are combined and consolidated. A methodological approach to the innovative development of the service sector is proposed. In contrast to existing methodologies, the author's approach takes into account the following stages: coordination of the strategy with the population of the territory and budgeting, analysis of the "failures" in the innovative development of service industries and budget creation based on the "failureproject-target approach". Moreover, when applying the above mentioned author's approach, "state failures" are also taken into account, project activities are developed with the greatest efficiency and there is a close connection between activities and targets. Also, the author proposes in the article innovative measures taken into account when developing a strategy for innovative development of services industries.
\end{abstract}

\section{Introduction}

Service sector today plays the main role in serving the public. Recently modern trends including outsourcing processes, digital development, import substitution and etc. have made the study of service sector development, its organizational and economic mechanisms, and especially innovative mechanisms, one of the most researched areas among Russian and foreign scientists. Besides, according to statistics, this area employs the largest number of the working-age population. Thus, N.V. Maslova notes that over the past decades the service sector has seen a significant growth: according to Russian Federation Federal State Statistics Service, $65 \%$ of the working-age population worked in the service sector in 2014 [1]. 
Therefore, we also study the issues of employment in the service sector, and their impact on the socio-economic development of territories.

In this article, we will focus on the study of formation and improvement of organizational and economic mechanisms for ensuring the innovative development of service sector.

Z.K. Omarova presented the following grouping of services that currently exist: "transport, communications, wholesale and retail trade, credit and finance, insurance, consumer services, cultural and recreational services and a block of social services education, health care, social services" [2].

Foreign authors propose the following range of services: trade, transport, information, educational, medical, financial and professional services [3].

The important role of innovation processes in the national economy makes it necessary to study them both at the macro level and at the level of individual economic entities in the economy. In this study, we will consider the innovative development of the service sector.

According to Wikipedia "innovation" is "an improvement introduced or in the process of introduction that provides an increase in the efficiency of processes and (or) in product quality demanded by the market" [4].

Studying the concept of "innovation", S.A. Agarkov, E.S. Kuznetsova and M.O. Gryaznova explained this concept as "the end result of innovative activities, which is a new or improved product introduced into the market, a new or improved technological process used in practice, or a new approach to social services" [5].

Besides, the above mentioned authors consolidated their position in their monograph: "innovation is a consequence of innovative activities; the specific part of innovation is change; the main function of innovative activities is change" [5].

Yu.A. Arutyunov and A.S. Sharanin proposed the following interpretation of the concept of "innovative development": "a qualitative change in products, technologies, investments accompanied by the expansion of market opportunities based on innovations" [6].

In her article O.I. Golovko [7] pointed out a number of functions attributed to innovations, in particular: "innovations accelerate tenological progress; innovations lead to the development of vertical value addition chains; basic innovations help organizations develop by increasing production capabilities and profits and, as a result, help to move beyond the limited local market."

Today scientists and researchers propose new and improve existing organizational and economic mechanisms to ensure the innovative development of the service sector. The following proposed mechanisms can be pointed out:

- E.S. Ryazak [8] substantiated "promising directions of innovative development of the service sector, including assistance of different-level management bodies to innovation processes in creating favorable conditions for increasing the level of innovation and economic performance";

- A.G. Bodunkova [9] supplemented the "concept of a "new service economy" by substantiating her personal approach to the analysis of a new quality of servicizing that ensures the quality of infrastructure for organizing and developing an innovative business and determined by the evolution of service innovations";

- S.A. Ilyina [10] substantiated "the need to form organizational and economic mechanisms to commercialize innovations in small and medium-sized enterprises: "a mechanism for accounting innovative enterprises", "tax incentive mechanisms", "direct state support mechanisms', "a mechanism to stimulate the participation of enterprises in the state order system"; "market mechanisms";

- A.A. Al-Nsur [11] identified "key directions to achieve a harmonious and balanced innovative development of the service sector, such as: improving the quality of services provided in Russia up to world standards, raising subsidies for international projects to 
develop innovations in the service sector, network interaction between scientific organizations and enterprises providing services based on mobile research groups, and etc.";

- A.V. Pavlova, A.V. Novikova, A.D. Pogulich and A.D. Chudnovsky [12] defined "the organizational and economic mechanism for the innovative development of the service sector, ensuring the coordination of the interests of the federal, regional and municipal authorities."

The author has consolidated the proposals of Russian scientists and researchers in terms of the formation and improvement of organizational and economic mechanisms for the innovative development of the service industries (Table 1).

Table 1. Organizational and economic mechanisms for innovative development of the service sector in Russia

\begin{tabular}{|c|c|c|c|}
\hline $\begin{array}{l}\text { Service } \\
\text { sector } \\
\text { industrie } \\
\quad \mathrm{s} \\
\end{array}$ & $\begin{array}{l}\text { Scientist } \\
\text { s and } \\
\text { research } \\
\text { ers }\end{array}$ & $\begin{array}{c}\text { Proposed organizational and economic } \\
\text { mechanisms for the innovative development of } \\
\text { the service sector }\end{array}$ & Implementation result \\
\hline \multirow[t]{3}{*}{ Transport } & $\begin{array}{l}\text { V.V. } \\
\text { Guzhov } \\
{[13]}\end{array}$ & $\begin{array}{l}\text { V.V. Guzhov proposed the following } \\
\text { mechanisms: creation of logistics centers; use of } \\
\text { innovative and energy-saving technologies; } \\
\text { introduction of satellite navigation technologies } \\
\text { in transport sector and providing staff for the } \\
\text { transport industry. } \\
\end{array}$ & $\begin{array}{l}\text { A significant improvement } \\
\text { in the use of the country's } \\
\text { transport potential. }\end{array}$ \\
\hline & $\begin{array}{l}\text { E.V. } \\
\text { Asaulenk } \\
\text { o [14] }\end{array}$ & $\begin{array}{l}\text { A model has been developed for choosing an } \\
\text { effective approach (competitive, administrative, } \\
\text { cooperative, proactive) to stimulate the } \\
\text { innovative development of railway transport. }\end{array}$ & $\begin{array}{l}\text { Progressive innovative } \\
\text { development of railway } \\
\text { transport }\end{array}$ \\
\hline & $\begin{array}{l}\text { D.A. } \\
\text { Kregel } \\
{[15]}\end{array}$ & $\begin{array}{c}\text { D.A. Kregel divided the mechanisms for } \\
\text { stimulating innovation in railway transport by the } \\
\text { degree of financial participation of the state and } \\
\text { by the nature of state incentives. }\end{array}$ & $\begin{array}{l}\text { Accelerating the process of } \\
\text { developing new } \\
\text { technologies. }\end{array}$ \\
\hline $\begin{array}{l}\text { Telecom } \\
\text { municati } \\
\text { on } \\
\text { service }\end{array}$ & $\begin{array}{l}\text { I.A. } \\
\text { Strelkova } \\
{[16]}\end{array}$ & $\begin{array}{l}\text { The following proposals were presented: } \\
\text { - Support for IP telephony with broadband access } \\
\text { technologies such as cable modems and digital } \\
\text { subscriber lines. } \\
\text { - Creation of a plan to stimulate private } \\
\text { investment into the development of optical fiber } \\
\text { networks in rural areas to expand network } \\
\text { coverage throughout the country. }\end{array}$ & $\begin{array}{l}\text { Effective functioning of } \\
\text { modern production and } \\
\text { national markets. }\end{array}$ \\
\hline \multirow[t]{2}{*}{$\begin{array}{l}\text { Wholesal } \\
\text { e and } \\
\text { retail } \\
\text { trade }\end{array}$} & $\begin{array}{l}\text { N.V. } \\
\text { Semenov } \\
\text { a [17] }\end{array}$ & $\begin{array}{l}\text { The structural and logical diagram of the } \\
\text { organizational and economic mechanism for the } \\
\text { innovative development of a retail enterprise has } \\
\text { been supplemented. This diagram differs from } \\
\text { the existing ones in that: firstly, the planning } \\
\text { element is supplemented by the coordination of } \\
\text { the tasks of innovative development among } \\
\text { themselves; secondly, the planning element is } \\
\text { supplemented with stages: drawing up a set of } \\
\text { indicators. }\end{array}$ & $\begin{array}{l}\text { Development of innovative } \\
\text { management within the } \\
\text { service sector. }\end{array}$ \\
\hline & $\begin{array}{l}\text { V.Sh. } \\
\text { Ovasapya } \\
\text { n [18] }\end{array}$ & $\begin{array}{l}\text { A mechanism for organizing innovation in retail } \\
\text { trade networks has been proposed. }\end{array}$ & $\begin{array}{l}\text { Allows to determine } \\
\text { business partners and } \\
\text { competitors. }\end{array}$ \\
\hline \multirow[t]{2}{*}{$\begin{array}{l}\text { Credit } \\
\text { and } \\
\text { finance }\end{array}$} & $\begin{array}{l}\text { R.G. } \\
\text { Abasov } \\
{[19]}\end{array}$ & $\begin{array}{l}\text { A mechanism for bank financing of innovative } \\
\text { projects based on the development of the Public } \\
\text { Private Partnership model has been developed. }\end{array}$ & $\begin{array}{c}\text { Stimulation of } \\
\text { independence of the } \\
\text { domestic economy from } \\
\text { external sources. }\end{array}$ \\
\hline & $\begin{array}{c}\text { I. } \\
\text { V.Bespal } \\
\text { ova [20] }\end{array}$ & $\begin{array}{c}\text { A number of steps to reduce financial losses in } \\
\text { the event of an innovation risk has been } \\
\text { proposed. }\end{array}$ & $\begin{array}{l}\text { Introduction of scientific, } \\
\text { technical and } \\
\text { organizational innovations } \\
\text { in banking sector. }\end{array}$ \\
\hline
\end{tabular}


Continuation of Table 1.

\begin{tabular}{|c|c|c|c|}
\hline \multirow[t]{2}{*}{ Insurance } & $\begin{array}{l}\text { Yu.A. } \\
\text { Platonov } \\
\text { [21] }\end{array}$ & $\begin{array}{l}\text { The benefit of technological innovation is } \\
\text { substantiated: in particular, creation of an } \\
\text { automated information system for recording new } \\
\text { ideas, which is able to collect, analyze and } \\
\text { evaluate information in a large insurance } \\
\text { company. }\end{array}$ & $\begin{array}{l}\text { Ability to fully use the } \\
\text { intellectual potential of the } \\
\text { insurance company and } \\
\text { effectively respond to the } \\
\text { dynamic changes in the } \\
\text { external environment. }\end{array}$ \\
\hline & $\begin{array}{l}\text { Ya.G } \\
\text { Stupiche } \\
\text { va. [22] }\end{array}$ & $\begin{array}{l}\text { The following proposals have been presented: } \\
\text { increasing the value of insurance services, } \\
\text { obtaining qualitatively new benefits, shortening } \\
\text { the terms of service provision, reducing the total } \\
\text { cost of obtaining the service and etc. }\end{array}$ & $\begin{array}{l}\text { Effective management in } \\
\text { insurance, development of } \\
\text { the insurance market } \\
\text { infrastructure. }\end{array}$ \\
\hline $\begin{array}{l}\text { Consume } \\
\text { r services }\end{array}$ & $\begin{array}{l}\text { V.N. } \\
\text { Bokhano } \\
\text { v [23] }\end{array}$ & $\begin{array}{l}\text { The structure of the organizational and economic } \\
\text { mechanism of consumer services state regulation } \\
\text { has been developed. }\end{array}$ & $\begin{array}{l}\text { The economic policy of } \\
\text { state regulation is } \\
\text { determined based on the } \\
\text { characteristics of the } \\
\text { region. }\end{array}$ \\
\hline $\begin{array}{l}\text { Cultural } \\
\text { and } \\
\text { recreatio } \\
\quad \text { nal } \\
\text { services }\end{array}$ & $\begin{array}{l}\text { M.V. } \\
\text { Radchuk } \\
\text { [24] }\end{array}$ & $\begin{array}{l}\text { It has been argued that transformations in the } \\
\text { resort sector should be based on the results of } \\
\text { studying the role and place of needs for } \\
\text { recreational services in the structure of society's } \\
\text { needs. }\end{array}$ & $\begin{array}{l}\text { Improving the quality of } \\
\text { service delivery. }\end{array}$ \\
\hline \multirow{3}{*}{$\begin{array}{l}\text { Social } \\
\text { services - } \\
\text { education } \\
\text { healthcar } \\
\text { e, social } \\
\text { services }\end{array}$} & $\begin{array}{l}\text { G.O. } \\
\text { Iskandary } \\
\text { an }[25]\end{array}$ & $\begin{array}{l}\text { The theoretical and model presentation of the } \\
\text { organizational and economic mechanism of the } \\
\text { innovative development of the medical services } \\
\text { sector has been compiled. }\end{array}$ & $\begin{array}{c}\text { Substantiation of } \\
\text { promising directions of } \\
\text { innovative development of } \\
\text { medical services. }\end{array}$ \\
\hline & $\begin{array}{l}\text { N.V. } \\
\text { Bryksina } \\
\text { [26] }\end{array}$ & $\begin{array}{l}\text { The directions of development of healthcare } \\
\text { services are proposed, in particular: introduction } \\
\text { of "financial and economic managers of } \\
\text { healthcare"; development of insurance principles } \\
\text { in the Compulsory Health Insurance model; } \\
\text { introduction of "insurance representatives"; } \\
\text { development of medical professional non-profit } \\
\text { organizations, and others. }\end{array}$ & $\begin{array}{l}\text { Innovation-oriented } \\
\text { development of the health } \\
\text { services sector. }\end{array}$ \\
\hline & $\begin{array}{l}\text { V.G. } \\
\text { Shumeev } \\
{[27]}\end{array}$ & $\begin{array}{l}\text { The stages for organizing an effective social } \\
\text { policy are proposed. In particular: drawing up a } \\
\text { list of social services, social standards and norms } \\
\text { that determine the provision of social guarantees; } \\
\text { development of indicators of social structure and } \\
\text { infrastructure, norms for the provision of social } \\
\text { services; etc. }\end{array}$ & $\begin{array}{l}\text { Improving the } \\
\text { effectiveness of social } \\
\text { policy in the region. }\end{array}$ \\
\hline
\end{tabular}

The author also presents the organizational and economic mechanisms for innovative development of the service sector offered by foreign scientists.

Table 2. Organizational and economic mechanisms for innovative development of the service sector abroad

\begin{tabular}{|c|c|c|c|}
\hline Country & $\begin{array}{l}\text { Scientists and } \\
\text { researchers }\end{array}$ & $\begin{array}{l}\text { Proposed/existing organizational and economic } \\
\text { mechanisms for the innovative development of the } \\
\text { service sector abroad }\end{array}$ & $\begin{array}{l}\text { Implementation } \\
\text { result }\end{array}$ \\
\hline Germany & $\begin{array}{c}\text { German } \\
\text { Federal } \\
\text { Ministry of } \\
\text { Education } \\
\text { and Research } \\
\text { [28] }\end{array}$ & $\begin{array}{c}\text { German Federal Ministry of Education and Research } \\
\text { points to the development of more advanced } \\
\text { technologies to create new forms of service at } \\
\text { different skill levels. } \\
\text { They suggest expanding the number of custom } \\
\text { solution providers. } \\
\text { In addition, they note that Germany has developed a } \\
\text { strategy to provide new impulses for the } \\
\text { development of innovation in business and society. }\end{array}$ & $\begin{array}{l}\text { Creation of } \\
\text { services for new } \\
\text { markets. }\end{array}$ \\
\hline
\end{tabular}


Continuation of Table 2.

\begin{tabular}{|c|c|c|c|}
\hline & $\begin{array}{l}\text { Kleppel C., } \\
\text { Siegel D., } \\
\text { Ganz W. } \\
\text { [29]. }\end{array}$ & $\begin{array}{l}\text { Kleppel C., Siegel D. and Ganz W. point out that in } \\
\text { January } 2004 \text { a union of business, science and } \\
\text { government representatives was created in Germany } \\
\text { to create and develop innovations, promote new } \\
\text { synergies, and create a new climate of innovation in } \\
\text { the service sector. Today the union includes } 24 \\
\text { representatives. }\end{array}$ & $\begin{array}{l}\text { Innovative } \\
\text { development of } \\
\text { the service } \\
\text { sector. }\end{array}$ \\
\hline & $\begin{array}{l}\text { Meiren T., } \\
\text { Barth T.[30] }\end{array}$ & $\begin{array}{l}\text { Meiren T. and Barth T. state that concerning service } \\
\text { development, special attention is paid to } \\
\text { strengthening the integration of the market and } \\
\text { meeting the wishes of the client. } \\
\text { They celebrate the project "Holistic development of } \\
\text { services through Engineering service" implemented } \\
\text { by the German Federal Ministry of Education and } \\
\text { Research, which includes effective measures for the } \\
\text { development of services, implemented jointly by } \\
\text { industrial enterprises and service companies. }\end{array}$ & $\begin{array}{l}\text { Market } \\
\text { integration, } \\
\text { customer } \\
\text { satisfaction; } \\
\text { innovative } \\
\text { development of } \\
\text { the service } \\
\text { sector. }\end{array}$ \\
\hline \multirow[t]{2}{*}{ China } & Boden M.[31] & $\begin{array}{l}\text { Boden M. proposes to develop knowledge-intensive } \\
\text { services (including internationalization knowledge- } \\
\text { intensive services between China and Europe), to } \\
\text { stimulate innovation in terms of protecting } \\
\text { intellectual property } \\
\end{array}$ & $\begin{array}{c}\text { Progressive } \\
\text { development of } \\
\text { the service sector }\end{array}$ \\
\hline & $\begin{array}{l}\text { Hangzhou } \\
\text { Normal } \\
\text { University } \\
{[32]}\end{array}$ & $\begin{array}{l}\text { Hangzhou Normal University proposes to create and } \\
\text { implement a project on cooperation between } \\
\text { universities to implement measures for the innovative } \\
\text { development of the service sector. }\end{array}$ & $\begin{array}{l}\text { Increase in the } \\
\text { number of } \\
\text { activities for the } \\
\text { development of } \\
\text { the service } \\
\text { sector. }\end{array}$ \\
\hline USA & $\begin{array}{l}\text { United } \\
\text { Nations } \\
\text { Economic } \\
\text { Commission } \\
\text { for Europe } \\
\text { [33] }\end{array}$ & $\begin{array}{l}\text { United Nations Economic Commission for Europe } \\
\text { states the opinion that it is necessary to analyze the } \\
\text { relationship and mutual influence of the service } \\
\text { sector and technological production; proposes to } \\
\text { introduce benefits for service innovation; offers to } \\
\text { improve innovation policy on the supply in the } \\
\text { service sector. }\end{array}$ & $\begin{array}{l}\text { Increasing the } \\
\text { efficiency of } \\
\text { business and } \\
\text { territory } \\
\text { development. }\end{array}$ \\
\hline France & $\begin{array}{c}\text { Beylat J.L., } \\
\text { Tambourin P. } \\
\text { [34] }\end{array}$ & $\begin{array}{l}\text { Beylat J.L. and Tambourin P. argue that the state } \\
\text { innovation policy should be implemented, aimed at } \\
\text { supporting innovative companies (targeted funding, } \\
\text { preferential government procurement, encouraging } \\
\text { the creation of new jobs). }\end{array}$ & $\begin{array}{l}\text { Improving the } \\
\text { effectiveness of } \\
\text { the country's } \\
\text { state policy. }\end{array}$ \\
\hline $\begin{array}{c}\text { Czech } \\
\text { Republic }\end{array}$ & $\begin{array}{l}\text { Ministerstvo } \\
\text { dopravy[35] }\end{array}$ & $\begin{array}{c}\text { Ministerstvo dopravy states the particular importance } \\
\text { of the development of R\&D in the field of transport: } \\
\text { "the role of transport research and development is to } \\
\text { support and further develop modern society as a } \\
\text { whole." }\end{array}$ & $\begin{array}{l}\text { Improving the } \\
\text { quality of life of } \\
\text { the population. }\end{array}$ \\
\hline
\end{tabular}

\section{Materials and methods}

Many researchers and scientists have developed methodological recommendations for the study and implementation of innovations at service sector enterprises, including:

- A.N. Kuznetsov [36] has developed "guidelines for the study and implementation of innovations at enterprises of the service sector on the basis of consulting, leasing, franchising, joint ventures and business incubators, as well as basic innovative structures of research, educational organizations and venture firms";

- V. Molchanova [37] identifies "three main methodological positions of the innovative development of the regional service sector: use of criteria or standards, measurement of indicators and quantitative assessment; causal position, associated with finding causal relationships and explaining the results; a change-oriented position where assessment is 
associated with finding opportunities to improve results, overcome barriers, and reduce negative consequences";

- A.M. Gubernatorov [38] has developed a "project model to enhance the industry's innovative potential (using the example of the glass industry), which allows for a three-level decomposition from the business process "Management of the industry's innovative development";

- Ya.N. Abubakirov [39] has formulated "a methodological approach to defining the innovative potential in the service sector as a key characteristic of the industry, reflecting its ability to develop on a better basis - its assessment can be based on the theory of the duration of business cycles and changes in technological structures";

- V.V. Konteev [40] has developed a "mechanism for monitoring the quality of services in the urban consumer market, which is based on the interaction "service consumer - city administration - service sector enterprise"; he has also developed a technology for strategic planning in the sphere of municipal services.

Taking into account the above considerations, the authors proposed the following methodological approach to the innovative development of the service sector (Fig. 1).

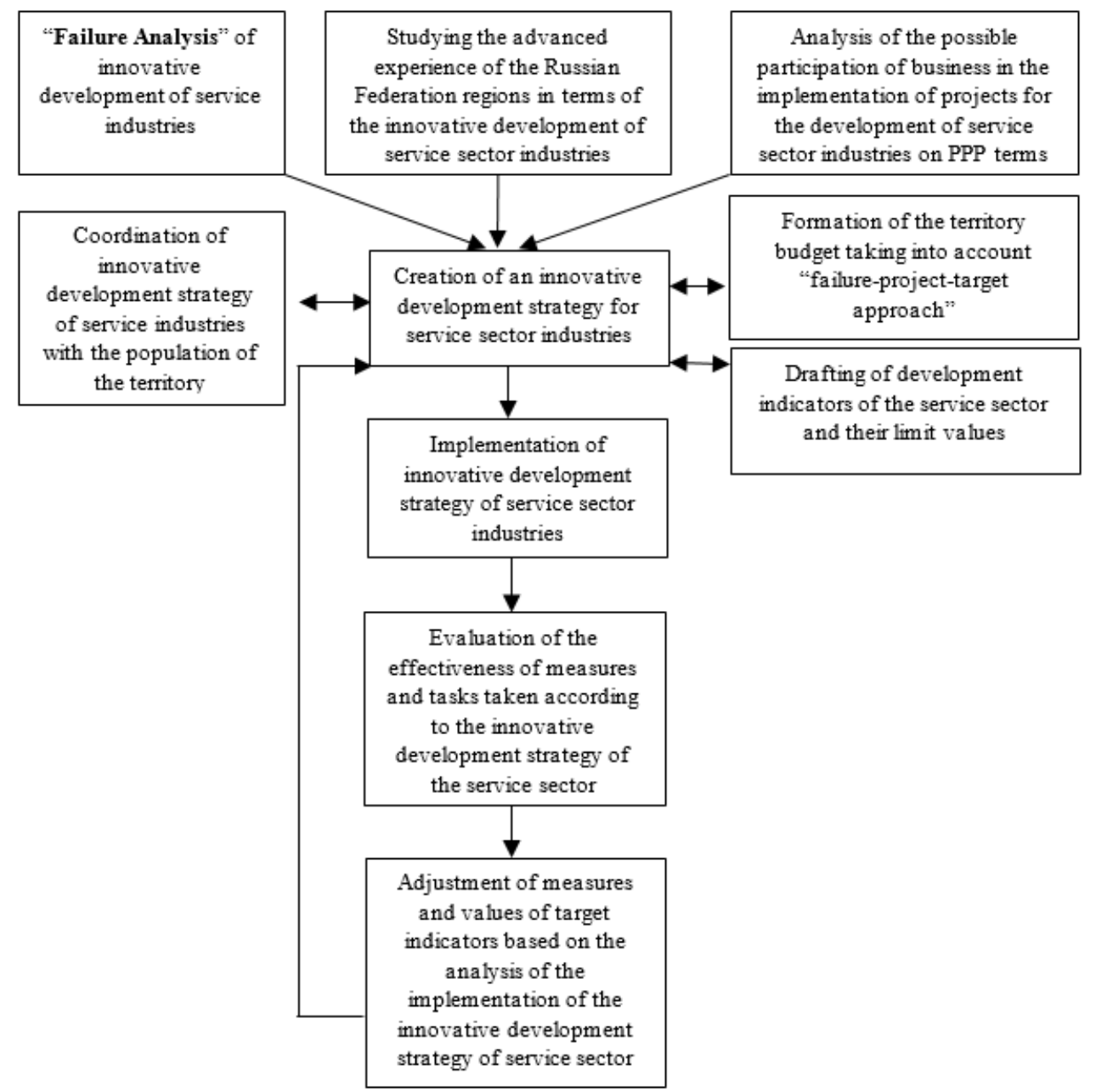

Fig. 1. Methodological approach to the innovative development of service sector industries 
At the same time, the study of "failures" is presented in S.G. Pyankova's Doctor of Economics degree work [41]. In particular, S.G. Pyankova formulates that "failures (fiasco) of the state are cases when the state is unable to ensure the efficient distribution and use of public resources".

In contrast to the existing methodologies, the author's approach takes into account the following stages: coordination of the strategy with the population of the territory and budget formation, analysis of "failures" of innovative development of service sector industries and formation of the territory budget taking into account "failure-project-target approach".

When applying the above author's approach, "state failures" are taken into account, activities within the project are designed with the greatest efficiency and there is a connection between activities and targets (each activity is aimed at achieving a certain target).

When developing such a strategy, the authors propose to take into account the following innovative activities (in the context of service sector industries) included in projects:

1. "Transport": development of a subway network in megacities; installation of child's seats in public transport (for children's safety); carrying out regular sanitization of vehicles.

2. "Telecommunications": introduction of state subsidies to provide Internet services and cellular communications with limited tariffs for general school students; providing navigation "badges" for general school students and preschool children.

3. "Wholesale and retail trade": the government maintains weekly subsidy packages for the nutrition of pensioners and children under 18.

4. "Credit and finance": expanding development institutions investment support to representatives of small and medium-sized businesses;

5. "Insurance": state subsidies for the insurance of children under 18.

6. "Consumer services": introduction of step-by-step accessibility schemes for the provision of household services in the territories.

7. "Cultural and recreational services": the organization and holding of cultural events in the territories on the condition of public-private partnership.

8. "Social services - education, healthcare, other social services": introduction of innovative educational parks in the territories for teaching school-age children; government subsidies for free preparatory courses for preschool children; introduction of "continuous family distance-learning" program; creation of a project to provide the poorest sections with free Internet (schoolchildren, students, pensioners).

In addition, article written by V. Blaginin, O. Ergunova and S. Pyankova, "Automobile transport infrastructure in the system of maintaining social well-being" [42] also proposes measures for the development of services in the "transport"" sector.

\section{Results and discussion}

After analyzing the organizational and economic mechanisms proposed by the Russian scientists to ensure innovative development of service sector industries, the following can be pointed out (in the sector):

- "transport": proposals cover the development of logistics flows, provision of the service sector with personnel, use of energy-saving technologies.

- "telecommunications": the issues of IP-telephony support, expansion of network coverage plans are disclosed.

- "wholesale and retail trade": proposals are aimed at creating an optimal system of material flows.

- "credit and finance": the development of public-private partnership model is taken into account.

- "insurance": creation of an automated information system of new ideas was proposed. 
- "consumer services": it was proposed to take into account regional characteristics when regulating consumer services.

- "cultural and recreational services": the necessity to study the needs in the structure of recreational services is revealed.

- "social services - education, healthcare, other social services": proposals are aimed at adjusting the norms for the provision of social services, introduction of "financial and economic health managers", development of medical professional non-profit organizations.

The proposals of foreign scientists are aimed at expanding not only economic, but also organizational mechanisms for innovative development of service industries: creating a union of business, science and government representatives to develop innovations; cooperation of universities for implementation innovative measures in the service sector; introduction of service sector innovation benefits; development of cross-country knowledgeintensive services.

The methodology proposed by the authors will make it possible to increase the efficiency of implementation of the innovative development strategy in the service sector, to introduce the formation of the territory budget based on the proposed "failure-project-target approach".

The measures proposed by the authors will expand the range of innovative development of the territory, increase the efficiency of the state and municipal services provision, increase the efficiency of spending of budget funds, and improve the quality of strategic planning of the territory.

\section{Conclusion}

Thus, at present, Russian and foreign scientists consider the problem of creation of organizational and economic mechanisms for the innovative development of service sector industries important and relevant. The authors' proposals are comprehensive and earmarked, aimed at efficient development of the service sector industries. The authors attach particular importance to the need to improve the quality of strategic planning of innovative development of service sector industries.

The author's research on this issue will be continued.

\section{References}

1. N.V. Maslova, Economy and Entrepreneurship, 5 (2017)

2. Z.K. Omarova, Fundamental research, 12 (2007)

3. Services Contribution to Manufacturing. Chapter 3. https://www.usitc.gov/publications/332/pub4440c.pdf

4. Wikipedia. https://ru.wikipedia.org/

5. S.A. Agarkov, E.S. Kuznetsova, M.O. Gryaznova, Innovation management and state innovation policy. M.E. Academy of Natural Sciences (2011)

6. Yu.A. Arutyunov, A.S. Sharanin, Creative Economy, 5(2) (2011)

7. O.I. Golovko, Economy and Management of the National Economy, 4 (137) (2016)

8. E.S. Ruzyak, Formation of an organizational and economic mechanism for the innovative development of economic activities in the service sector. Cand. Economics Dissertation 08.00.05 (2010)

9. A.G. Bodunkova, Organizational and economic mechanisms for managing an entrepreneurial university in the system of innovative development of the service sector. Cand. Economics Dissertation 08.00.05 (2014) 
10. S.A. Ilyina, Improving the organizational and economic mechanism for the commercialization of innovations in small and medium-sized enterprises. Cand. Economics Dissertation 08.00.05 (2016)

11. A.A. Al-Nsur, Improving the mechanism for managing the innovative development of the service sector. Cand. Economics Dissertation 08.00.05 (2013)

12. A.V. Pavlova, A.V. Novikova, O.V. Pogulich, A.D. Chudnovskiy, International review of management and marketing, 6(2S) (2016)

13. V.V. Guzhov, Transport business in Russia, 6 (2013)

14. E.V. Asaulenko, Stimulating the innovative development of railway transport. Author's abstract. Cand. Economics Dissertation 08.00.05 (2016)

15. D.A. Kregel, University Bulletin, 2 (2018)

16. I.A. Strelkova, Bulletin of Economics, Law and Sociology, 1 (2012)

17. N.V. Semenova, Improving the organizational and economic mechanism for the innovative development of retail enterprises. Cand. Economics Dissertation 08.00.08 (2012)

18. V.Sh. Ovasapyan, Organization of innovative activities in retail trade networks. Author. Cand. Economics Dissertation 08.00.05 (2008)

19. R.G. Abasov, Bank financing mechanisms for innovative economic development. Cand. Economics Dissertation 08.00.10 (2015)

20. I.V. Bespalova, Fundamental research, 12 (2015)

21. Yu. A. Platonov, Innovative development of insurance activities in modern Russia. Cand. Economics Dissertation 08.00.05 (2007)

22. Ya.G. Stupicheva, Naukovedenie, 2 (2013)

23. V.N. Bokhanov, Organizational and economic mechanism of state regulation of the development of consumer services for the population in the region. Cand. Economics Dissertation 08.00.05 (2002)

24. M.V. Radchuk., Bulletin of the Saratov State Social and Economic University (2012)

25. G.O. Iskanderyan, Formation of the organizational and economic mechanism for the innovative development of the medical services sector. Author. Cand. Economics Dissertation 08.00.05 (2014)

26. N.V. Bryksina, Innovative development of the service sector in the national economy: monograph (2016)

27. V.G. Shumeev, Mechanisms for the formation and implementation of social policy in the region in the context of modern Russian reforms (Political science aspect). Cand. Economics Dissertation 23.00.02 (2004)

28. Innovationen für die Produktion, Dienstleistung und Arbeit von morgen. Bundesministerium für Bildung und Forschung.

29. C. Kleppel, D. Siegel, W. Ganz, Services Made in Germany - Mit innovativen Dienstleistungen die Zukunft gestalten. Impulskreis Dienstleistungen in der Initiative «Partner für Innovation» (2005)

30. T. Meiren, T. Barth, Service Engineering in Unternehmen umsetzen. Leitfaden für die Entwicklung von Dienstleistungen. Fraunhofer IRB Verlag (2002)

31. M. Boden, Knowledge-intensive service industry and innovation (2003). http://www.swstsg.com/PDFDATA/data/006/010/207633.pdf/ 
32. The research on organizational service orientation and its effect on performance of entrepreneurial firms. Hangzhou Normal University (2011)

33. United Nations Economic Commission for Europe. Promoting innovation in the services sector. Review of experiences and policies. United Nations New York and Geneva (2011)

34. J.-L. Beylat, P. Tambourin, L'Innovation un enjeu majeur pour la France. Dynamiser la croissance des entreprises innovantes (2013)

35. Koncepce vy z zkumu, vy z voje a inovaci z v rezortu dopravy do roku 2030 (2018).

36. A.N. Kuznetsov, Innovation as the basis for the development and improvement of small and medium-sized enterprises in the service sector. Author's abstract. Cand. Economics Dissertation 08.00.05 (2005)

37. V. Molchanova, Problems of economics and management of enterprises, industries, complexes. Center for the Development of Scientific Cooperation

38. A.M. Gubernatorov, Methodology and organization of management of innovative development of the industry. Author's abstract. Cand. Economics Dissertation 0.00.05 (2016)

39. Ya.N. Abubakirov, Methodological approaches to developing a strategy for innovative development of the service sector. Author's abstract. Cand. Economics Dissertation (2013)

40. V. V. Konteev, Formation of a strategy for the development of the service sector of the largest city: on the example of the municipal formation of Ekaterinburg. Cand. Economics Dissertation 08.00.05 (2006)

41. S.G. Pyankova, Theory and methodology of systemic socio-economic development of single-industry territories based on institutional renewal: Doct. Economics Dissertation 08.00.05 (2015)

42. V. Blaginin, O. Ergunova, S. Pyankova, Conference Title Abbreviation \& a Year Conference Title. The European Proceedibgs of Social \& Behavioural Sciences (2018) 